\title{
DNA Barcode Reference Library Construction and Genetic Diversity and Structure Analysis of Amomum Villosum Lour. Populations in Guangdong Province
}

\section{Lu Gong}

Guangdong Provincial Hospital of Traditional Chinese Medicine https://orcid.org/0000-0002-12450506

\section{Danchun Zhang}

Guangdong Provincial Hospital of Traditional Chinese Medicine

\section{Xiaoxia Ding}

Guangdong Provincial Hospital of Traditional Chinese Medicine

\section{Wan Guan}

Guangdong Provincial Hospital of Traditional Chinese Medicine

Xiaohui Qiu

Guangdong Provincial Hospital of Traditional Chinese Medicine

Zhihai Huang ( $\square$ zhhuang7308@163.com )

Guangdong Provincial Hospital of Traditional Chinese Medicine

\section{Research}

Keywords: DNA barcoding, polymorphism, ISSR band, AMOVA analysis

Posted Date: May 5th, 2021

DOI: https://doi.org/10.21203/rs.3.rs-463520/v1

License: (9) This work is licensed under a Creative Commons Attribution 4.0 International License. Read Full License 


\section{Abstract \\ Background}

Amomum villosum Lour. is the plant of a famous traditional Chinese medicine Amomi Fructus and its habitat has been frequently destroyed that seriously threatened its germplasm resources. The genetic diversity has great significance to the optimization of germplasm resources and protection of populations, but that of $A$. villosum is unclear. In this study, we analyzed the genetic diversity and genetic structures of $A$. villosum populations in Guangdong and constructed a local reference DNA barcode library for the purpose of more appropriate protecting measures.

\section{Methods}

DNA barcoding and ISSR markers were used to investigate the population genetics of $A$. villosum. Five universal DNA barcodes were amplified and constructed a DNA barcode reference library. Parameters including percentage of polymorphic sites (PPB), number of alleles ( $\mathrm{Na}$ ), effective number of alleles $(\mathrm{Ne})$, Nei's gene diversity index $(\mathrm{H})$ and Shannon's polymorphism information index $(\mathrm{I})$ were calculated for the assessment of genetic diversity. Genetic structure was revealed by Nei's gene differentiation coefficient (Gst), total population genetic diversity $(\mathrm{Ht})$, intra-group genetic diversity $(\mathrm{Hs})$ and gene flow $(\mathrm{Nm})$. AMOVA analysis, Mantel tests, UPGMA dendrogram and PCoA analysis were used to elucidate the genetic differentiation and the relationship among populations.

\section{Results}

531 sequences of five DNA barcodes were gained and all the sequences of the each barcode had no variation sites. A total of 66 ISSR bands were generated from A. villosum populations by the selected 6 ISSR primers. And 56 bands were amplified polymorphic with the percentage was $84.85 \%$ for all the seven $A$. villosum populations. The $A$. villosum populations showed high genetic diversity $(H=0.3281, \mathrm{I}=$ $0.4895)$ whereas the gene flow was weak $(\mathrm{Nm}=0.6143)$. Gst $(0.4487)$ and AMOVA analysis indicated that there's obvious genetic differentiation among $A$. villosum populations and more genetic variations existed in within population. The genetic relationship of each population was relatively close as the genetic distances were between 0.0844 and 0.3347 .

\section{Conclusions}

Overall, this study confirmed a high genetic diversity but weak gene flow of $A$. villosum in Guangdong province, especially in Amomi Fructus's Daodi producing area, Yangchun city. And a local DNA barcode reference library containing 531 sequences were subsequently constructed; facilitating the identification, conservation, breeding and cultivation of A. villosum. 


\section{Introduction}

Amomum villosum Lour. is a medicinal plant of Zingiberaceae family mainly grown in southern China. Its ripe and dried fruit Amomi Fructus is the famous traditional Chinese medicine (TCM) with the effects of dampening appetite, warming the spleen to stop diarrhea, regulating qi and relieving the fetus. Modern pharmacological studies show that, Amomi Fructus has great activities of anti-ulceration, anti-diarrhea, anti-inflammatory and antimicrobial [1]. In addition, Amomi Fructus is also widely used in food, liquors, and tea as the health product and condiment. Yangchun City located in Guangdong Province is considered the Daodi (genuine) producing area of Amomi Fructus for its high quality. With the rapid development of the city as well as traditional Chinese medicine business, the habitat of $A$. villosum has been frequently destroyed that seriously threatened its germplasm resources [2]. In 2016, Amomi Fructus from Yangchun was selected as one of the eight legally protected TCM varieties in Guangdong Province [3].

The genetic diversity of a species is the basis for its survival and evolution, which is of great significance to the analysis of evolutionary polymorphism, genetic relationship, and optimization of germplasm resources and protection of populations. Polymerase Chain Reaction (PCR)-based molecular markers have been widely used in the analysis of plant genetic diversity. Among them, Inter-Simple Sequence Repeat (ISSR) is fast and efficient, with the characteristics of high polymorphism, high reliability, low cost, and does not require pre-determination of target sequence information [4, 5]. Another marker, DNA barcodes, proposed in 2003 can not only be used in biological identification, but also in genetic diversity analysis [6, 7].

$\mathrm{COI}$ was an efficient species identification tool for animals and frequently used in genetic diversity analysis of animals [8]. In plants, however, low substitution rates of mitochondrial DNA have made it unsuitable, and some other barcoding regions were researched as alternatives [9]. In the current study, ISSR and five DNA barcodes ITS2, $p s b A-t r n H$, ITS, matK and $r b c L$ were used to investigate the genetic diversity of seven populations of $A$. villosum in Guangdong Province, especially in the Daodi producing area of Amomi Fructus, Yangchun City. It will provide insights into the identification, conservation, breeding and cultivation of $A$. villosum.

\section{Materials And Methods}

\section{Plant Material Sampling}

A total of 141 samples of 7 A. villosum populations were collected in Guangdong Province from August to November 2018. Six of them were in Yangchun City and the other one was in Maoming City. Population ZY was collected from a deserted germplasm garden containing A. villosum plants coming from Guangdong (Jinhuakeng), Yunnan and Guangxi provinces and a foreign country Myanmar. The sampled plants were identified by Huang Zhihai, the chief Chinese pharmacist of the Second Clinical College of Guangzhou University of Chinese Medicine. Fresh and healthy leaves were removed from the 
plants, dried and preserved in silica gel right now in the field, then stored in an ultra-low temperature refrigerator (eppendorf, Hamburg, Germany) when came back to the laboratory. Detailed information and geographic location of the samples see Table 1 and Fig. 1.

\section{DNA extraction, PCR amplification and sequencing}

The total DNA was extracted using a DP305 plant DNA kit (TIANGEN Biotech Co., Ltd., Beijing, China). The NanoDrop2000 ultra-micro ultriolet spectrophotometer (Thermo Scientific, MIT, USA) was used to determine the DNA concentration and purity. The PCR amplification reaction system of the experiment contained 2هTaq PCR Mix $12.5 \mu \mathrm{L}$, forward primer $(2.5 \mu \mathrm{M}) 1.0 \mu \mathrm{L}$, reverse primer $(2.5 \mu \mathrm{M}) 1.0 \mu \mathrm{L}$, genomic DNA $2.0 \mu \mathrm{L}$ and added up to $25 \mu \mathrm{L}$ with $\mathrm{ddH}_{2} \mathrm{O}$. The primer sequences and amplification conditions of different DNA barcodes were shown in Table S1. All amplification reactions were completed on the ProFlex PCR instrument (Life Technologies, New York, USA). PCR products were sent to Shanghai Majorbio Pharmaceutical Biotechnology Co., Ltd Guangzhou Branch to be sequenced.

\section{ISSR-PCR amplification system}

100 ISSR universal primer sequences published by Columbia University were screened [10]. And 6 primers that produced clear and reproducible banding patterns were selected (Table 3 ). ISSR-PCR amplifications were performed on 38 individuals randomly chosen from seven $A$. villosum populations (Table 4 ). The $20 \mu \mathrm{L}$ ISSR reaction volume including $10 \mu \mathrm{L} 2$ X PCR Mix (containing dye, $\mathrm{MgCl}_{2}$, dNTPs), $2 \mu \mathrm{L}$ template DNA, $1 \mu \mathrm{LISSR}$ selected primer and $7 \mu \mathrm{L} \mathrm{ddH}_{2} \mathrm{O}$. The ISSR PCR amplification was programmed in the ProFlex thermocycler as follows: predenaturation at $94{ }^{\circ} \mathrm{C}$ for $5 \mathrm{~min}, 35$ cycles of denaturation at $94{ }^{\circ} \mathrm{C}$ for $45 \mathrm{~s}$, annealing at the $46.83-56.60^{\circ} \mathrm{C}$ of the primer for $45 \mathrm{~s}$, extension at $72{ }^{\circ} \mathrm{C}$ for $2 \mathrm{~min}$, with a final extension at $72{ }^{\circ} \mathrm{C}$ for 5 min and preservation at $4{ }^{\circ} \mathrm{C}$. ISSR-PCR products were separated on a $2 \%$ agarose gel stained with Goldview by electrophoresis in 1×TAE buffer at $80 \mathrm{~V}$. The gels were visualized under UV light and photographed with a ChemiDoc imaging system (Bio-Rad, California, USA). The molecular weights of ISSR-PCR products were estimated using a 100bp Plus DNA Ladder (TIANGEN Biotech Co., Ltd., Beijing, China).

\section{Data analysis}

The two-way sequenced peaks of DNA barcodes were evaluated and assembled by CondonCode Aligner v8.0.1 software [11]. Low-quality areas at both ends of the assembled sequences were removed. ITS2 barcodes were annotated by cutting off the conserved $5.8 \mathrm{~S}$ and $28 \mathrm{~S}$ motifs based on HMM [12] at the ITS2 database [13]. Mega6.0 software was used to align DNA barcode sequences and calculate sequence statistics including the base composition ratio, GC content, heterotopic site information, conservative site and parsimony informative sites [14]. Haplotype sequences for each barcodes were exhibited in the two-dimensional code picture. In the picture, each vertical line represented a nucleotide base $(\square \mathrm{A} \square \mathrm{T} \backsim \mathrm{C} \square \mathrm{G})$, and the two-dimensional code on the right could be scanned directly with the DNA sequence. 
Reproducible ISSR-PCR bands were determined with the help of the GelPro32 software and manual correction. These clear bands were scored as either present (1) or absent (0), thus generating an ISSR phenotype data matrix. And the data matrix was imported in Popgene32 software to analyze genetic diversity and genetic structure [15]. Genetic diversity parameters included percentage of polymorphic sites (PPB), number of alleles ( $\mathrm{Na}$ ), effective number of alleles (Ne), Nei's gene diversity index $(\mathrm{H})$ and Shannon's polymorphism information index (I) were calculated. Genetic structure parameters including Nei's gene differentiation coefficient (Gst), total population genetic diversity $(\mathrm{Ht})$, intra-group genetic diversity $(\mathrm{Hs})$ and gene flow $(\mathrm{Nm})$ were calculated. GenAlEx 6.502 software was used to estimate the components of genetic variance within and among populations by analysis of molecular variance (AMOVA) and to assess the correlation between population genetic distance and geographic distance by Mantel tests [16]. Genetic distances among populations were calculated and a UPGMA dendrogram was constructed by using NTSYS 2.10e [17].

\section{Results And Analysis}

\section{DNA barcode reference library construction}

We extracted the genomic DNA from 141 samples of $A$. villosum. The OD260/280 was 1.76-1.98 for all the DNA samples and the concentration was $73.70-1294.80 \mathrm{ng} / \mu \mathrm{L}$. Five DNA barcodes of all the samples were amplified and sequenced bi-directionally. The PCR amplification and sequencing results were shown in Table 2. It showed that the success rate of sequencing for each barcode was rbcL $(100.00 \%)>$ ITS $(98.58 \%)>$ ITS2 $(95.04 \%)>p s b A-\operatorname{trnH}(53.90 \%)>$ matK $(29.08 \%)$. The ranking of the success rate of PCR amplification was consistent with that of sequencing. Thus, these sequences constructed the DNA barcode reference library of $A$. villosum in Guangdong Province.

We also analyzed the sequences of each barcode we obtained. All the sequences of the five barcodes had no variation sites, showing a strong conservation. Among the five DNA barcodes, ITS2 had the shortest sequence length and the highest GC content. The sequences of each barcode were shown in Fig. 2 .

\section{ISSR polymorphism and genetic diversity}

We established the ISSR-PCR system for $A$. villosum. The ISSR-PCR fragments of $A$. villosum populations ranged from $300 \mathrm{bp}$ to $2000 \mathrm{bp}$. An example of amplified profiles was shown in Fig. S1. A total of 66 ISSR bands were generated from $A$. villosum populations by the selected 6 primers. Among them, 56 bands were polymorphic, thus the percentage of polymorphic bands was $84.85 \%$ for all the seven $A$. villosum populations. For each primer, it amplified 6-14 bands with the polymorphic ratio was $64.29 \%-100.0 \%$. The results were shown in Table 3.

Genetic diversity information of A. villosum populations analyzed by Popgene 32 was shown in Table 4 . Among the seven populations of $A$. villosum, population $\mathrm{ZY}$ had the highest genetic diversity ( $\mathrm{PPB}=71.21 \%, \mathrm{Na}=1.7121, \mathrm{Ne}=1.4240, \mathrm{H}=0.2536, \mathrm{l}=0.3816$ ) while population TK had the lowest genetic 
diversity (PPB=28.79\%, $\mathrm{Na}=1.2879, \mathrm{Ne}=1.1848, \mathrm{H}=0.1117, \mathrm{I}=0.1658)$. At the species level, the value of $\mathrm{Na}$, $\mathrm{Ne}, \mathrm{H}$ and I were $1.9394,1.5662,0.3281$ and 0.4895 , respectively.

\section{Genetic structure of A. villosum populations}

Genetic structure information of $A$. villosum populations analyzed by Popgene 32 was shown in Table 5. Total genetic diversity $(\mathrm{Ht})$ of the 7 populations was 0.3299 , while the within population genetic diversity was 0.1819 . Gene differentiation coefficient (Gst) was 0.4487 , indicating that $55.13 \%$ of the genetic variation was existed within populations. The result was similar to that of molecular variance analysis (AMOVA), which showing 68.74\% ( $P=0.001)$ genetic variation was in within populations while $31.26 \%$ $(P=0.001)$ was between populations (Table 6). Additionally, the gene flow (Nm) among different populations was 0.6143 .

\section{Genetic distance and cluster analysis}

Genetic distance is the main indicator to examine the degree of genetic differentiation and the relationship between groups. The genetic distances of 7 populations were between 0.0844 and 0.3347 (Table 7). Among them, the smallest genetic distance was between ZJD and TK population (0.0844), and the largest one was between XFC and YC population (0.3347). Mantel test carried out with NTSYS-pc 2.0 indicated that the genetic distance and geographical distance were not significantly correlated $(r=$ $0.02698, \mathrm{P}=0.5504)$ (Fig. 3).

The UPGMA clustering map of populations based on genetic similarity coefficient was constructed using the data of Nei's genetic distance of seven populations (Fig. 4). A. villosum populations were divided into three groups at the similarity coefficient of 0.84 . Three populations ZJD, TK and ZY formed one group.

Three populations GY, MM and YC formed another group. One population XFC formed a single group. The results of PCoA based on the unbiased pair $\Phi$ st matrix of Nei were consistent with UPGMA cluster analysis. And the first two principal components accounted for $48.04 \%$ of the total variation of ISSR markers indicating from PCoA (Fig. 5).

\section{Discussion}

Many DNA barcode reference libraries have been constructed for the purpose of a more rapid and accurate species identification $[18,19]$. In this study, five DNA barcodes ITS2, psbA-trnH, ITS, matK and $r b c L$ were amplified and sequenced from 141 individuals of seven $A$. villosum populations and finally 531 sequences were obtained. Thus the first local DNA barcode reference library of $A$. villosum in Guangdong Province was constructed. Fruits from the same genus plants, especially $A$. xanthioides Wall. ex Baker and $A$. longiligulare T.L. Wu are very morphologically similar to $A$. villosum's and are also the genuine sources of Amomi Fructus. In addition, other adulterants of Amomi Fructus are sold in the market [20]. Huang etc have used seven DNA barcodes to identify the three genuine germplasms of Amomi Fructus [21]. An ideal DNA barcode should be easily retrievable and bi-directionally sequenced, and provide maximal discrimination among species [9]. From our results, the highest PCR amplification and 
sequencing success rate of the five DNA barcodes for $A$. villosum was $r b c L$. For a more comprehensive assessment of discrimination power of DNA barcodes, it needs more investigations for discriminating power with adulterants of $A$. villosum included.

DNA markers especially ITS sequences are used in plant population genetic analysis [22]. In this study, we aligned the sequences within the DNA barcodes, but no variation sites of the five barcodes were found. Therefore, genetic diversity could not be analyzed by these DNA barcode markers. It might be caused by the narrow geographic collection of $A$. villosum populations [23]. Though intra-specific divergence could occur at a very high rate within geographically isolated populations [24], it seems that the geographic areas should be wide enough for the populations that could be analyzed of genetic diversity by DNA barcodes. And this is confirmed by other studies [25]. In fact, species identification and genetic diversity are two conflicting problems for the barcoding approach and these problems have to be dealt at the library construction stage [26]. Limited by sampling, however, how much variation is actually needed to separate species is not known with certainty[23]. It needs further research on this topic of field.

Then we analyzed the genetic diversity and genetic structure of $A$. villosum populations by ISSR marker through the whole genome. The results indicated that germplasm materials of $A$. villosum in Yangchun had relatively higher genetic diversity $(\mathrm{H}=0.3281, \mathrm{I}=0.3816)$. Among the seven populations, population ZY had the highest genetic diversity, this is consistent with the fact that it had a diverse germplasm resources and made the research results more reliable. The Gst results $(0.4487)$ indicated that there's obvious genetic differentiation among $A$. villosum populations [27] and more genetic variations existed in within populations. It was also confirmed by the AMOVA analysis. The gene flow value $(\mathrm{Nm}=0.6143)$ revealed that genetic drift was the main cause for genetic variations among populations [28]. The weak gene flow of $A$. villosum populations is probably due to its pollination style and the habitat fragmentation. A. villosum is extremely difficult to self-pollinate caused by its morphological structure of flowers. Due to lacking of pollinating insects, $A$. villosum in Guangdong mainly relies on artifificial pollination. The gene flow is consequently restricted to a small population. Another reason is that, habitat fragmentation of $A$. villosum in Yangchun is likely to reduce the exchange of spores between populations.

Amomi Fructus has been used in China for more than a thousand years and was mainly imported from abroad for a long history period. A. villosum has been cultivated in Yangchun for some 200 years and then was introduced into Guangxi, Yunnan and Fujian provinces in southern China [29]. The species with high genetic variation can resist the survival pressure caused by various environmental changes. $A$. villosum populations in Guangdong Province especially in the Daodi producing area of Amomi Fructus, Yangchun City, have high genetic diversity inferred from our study. And Yangchun has expanded the planting area of $A$. villosum in recent years. These are good news for $A$. villosum protection and cultivation. Though, considering the small populations and the increasingly fragmented habitat as well as the lower gene flow of $A$. villosum, we need to take continuous measures to protect the genetic resources of the species.

\section{Conclusion}


In the present study, a local DNA barcode reference library containing 531 sequences were constructed from 141 samples of seven $A$. villosum populations in Guangdong Province. On the other hand, the $A$. villosum populations have high genetic diversity but the gene flow was weak revealed by ISSR markers. The genetic relationship of each population was relatively close. More measures are needed to protect the genetic resources of $A$. villosum in Guangdong province, especially in Amomi Fructus's Daodi producing area, Yangchun city.

\section{Declarations}

\section{Ethics approval and consent to participate}

Not applicable.

\section{Consent for publication}

Not applicable.

\section{Availability of data and materials}

All data generated or analyzed during this study are included in this published article and its supplementary information files except for some ISSR-PCR electrophoretic maps. They are available from the corresponding author on reasonable request.

\section{Competing interests}

The authors declare that they have no competing interests.

\section{Funding}

This work was supported by grants from Guangdong Forestry Department (2017KT1835), Guangdong Provincial Medicial Products Administration (2020ZDB25, 002009) and Guangdong Provincial Bureau of traditional Chinese Medicine (20192026).

\section{Authors' contributions}

Lu Gong designed the experiment, analyzed the results and revised the manuscript. Danchun Zhang completed the experiment, data analysis and the draft manuscript. Xiaoxia Ding helped with sample collections and the experiment. Wan Guan helped do data analysis. Xiaohui Qiu made contributions to the conception of this work. Zhihai Huang made the conception and gained the supporting funds of this work.

\section{Acknowledgements}

The authors would like to thank Runfa Li, the technical director of TamKan.Agricultural development Co.,Ltd for the help of sampling. We also thank Baosheng Liao for providing us the program that 
generating the pictures of DNA barcodes.

\section{References}

1. Zhu C, Ni W, Yang C, Zhang T, Yu J. Therapeutic effect of amomum villosum on inflammatory bowel disease in rats. Front Pharmacol. 2018;9:639.

2. Ouyang X.. (2010). Resource Investigation and Quality Evaluation on Amomi Fructus in Yangchun. (Doctoral dissertation, Guangzhou University of Chinese Medicine).

3. Wei X, Zhong JJ. (2017). Discussion on legislation for authentic Chinese Medicinal Materials protection. Journal of Guangzhou University of Traditional Chinese Medicine (1), 113-117.

4. Grover A, Sharma PC. Development and use of molecular markers: past and present. Crit Rev Biotechnol. 2016;36(2):290.

5. Wu W, Chen F, Yeh K, Chen J.. (2018). Issr analysis of genetic diversity and structure of plum varieties cultivated in southern china. Biology, 8(1).

6. Hebert P, Cywinska A, Ball SL, Dewaard JR.. (2003). Biological identification through dna barcodes. Proceedings of the Royal Society B: Biological ences, 270(1512), 313-321.

7. Tamboli AS, Patil SM, Gholave AR, Kadam SK, Kotibhaskar SV, Yadav SR, et al. Phylogenetic analysis, genetic diversity and relationships between the recently segregated species of corynandra and cleoserrata from the genus cleome using dna barcoding and molecular markers. C R Biol; 2016. pp. 123-32.

8. Manel S, Guerin PE, Mouillot D, Blanchet S, Velez L, Albouy C, et al. Global determinants of freshwater and marine fish genetic diversity. Nature Communications, 11.

9. Group C. A dna barcode for land plants. Proc Natl Acad Sci USA. 2009;106(31):12794-7.

10. Zhang Q, Luo Z. Issr technology and its applications in fruit trees. Journal of Fruit Science; 2004.

11. Bonfield JK, Cristina R, Rodger S. Automated detection of point mutations using fluorescent sequence trace subtraction. Nucleic Acids Res. 1998;26(14):3404-9.

12. Keller A, Schleicher T, Schultz J, Müller T, Dandekar T, Wolf M. 5.8s-28s rrna interaction and hmmbased its2 annotation. Gene. 2009;430(1-2):50-7.

13. Ankenbrand MJ, Alexander K, Matthias W, S Jörg, \& Frank F.. Its2 database v: twice as much. Molecular Biology \& Evolution(11), 3030.

14. Tamura K, Stecher G, Peterson D, Filipski A, Kumar S.. (2013). Mega6: molecular evolutionary genetics analysis version 6.0. Molecular Biology Evolution, 30(12), 2725-9.

15. Yeh F, Yang R, Boyle T, Ye Z, Mao J, Francis CY, et al. POPGENE, version 1.31. The User-Friendly Shareware for Population Genetic Analysis; 1999.

16. Guillot G, Rousset F.. (2013). Dismantling the mantel tests. Methods in Ecology and Evolution, 4(4).

17. Rohlf FJ. (2000). Ntsys-pc 2.0. numerical taxonomy and multivariate analysis system. NTSYS-Pc : Numerical Taxonomy and Multivariate Analysis System, 2.1. 
18. Gong L, Qiu XH, Huang J, Xu W, Bai JQ, Zhang J, et al. (2018). Constructing a dna barcode reference library for southern herbs in china: a resource for authentication of southern chinese medicine. PLoS ONE, 13(7).

19. Mosa KA, Gairola S, Jamdade R, El-Keblawy A, Shaer K, Harthi E, et al. (2018). The promise of molecular and genomic techniques for biodiversity research and dna barcoding of the arabian peninsula flora. frontiers in plant science, 2018, 9.

20. Su Ch, Du XJ, Liu XT, Song XX, Wang Y, Wang ShH. Quality Analysis on Fructus Amomum and Its Prepared Slices. Chinese Pharmaceutical Affairs. 2018;32(11):39-45.

21. Huang Q, Duan Z, Yang J, Ma X, Zhan R, Xu H, et al. Snp typing for germplasm identification of amomum villosum lour. based on dna barcoding markers. PLoS ONE. 2014;9(12):e114940.

22. Li Q, Guo X, Niu JF, Duojie DZ, Li XJ, Opgenoorth L, Zou JB.. (2020). Molecular Phylogeography and Evolutionary History of the Endemic Species Corydalis hendersonii (Papaveraceae) on the Tibetan Plateau Inferred From Chloroplast DNA and ITS Sequence Variation. Frontiers in Plant Science, e00436.

23. Phillips JD, Gillis DJ, Hanner RH. Incomplete estimates of genetic diversity within species: implications for dna barcoding. Ecology and Evolution; 2019.

24. Hebert P, Ryan GT.. (2005). The promise of dna barcoding for taxonomy. Systematic Biology(5), 852859.

25. Poyraz, Ismail. Comparison of its, rapd and issr from dna-based genetic diversity techniques. Comptes Rendus Biologies; 2016.

26. Sarwat M, Yamdagni MM. Dna barcoding, microarrays and next generation sequencing: recent tools for genetic diversity estimation and authentication of medicinal plants. Crit Rev Biotechnol. 2014;36(2):191.

27. Wright S. Evolution And The Genetics Of Populations Vol-4. University of Chicago Press; 1984.

28. Slatkin, \& M. Gene flow and the geographic structure of natural populations. Science. 1987;236(4803):787-92.

29. Chen Caiying Z. Ruoting, \& Wang Xiaoping. (2011). Research on the Origin of Amomum villosum Varieties and Germplasm Resources. Journal of Shandong University of TCM, 035(004), 354-7.

\section{Tables}

Table 1 Sampling information of $A$. villosum populations in Guangdong Province 


\begin{tabular}{|llllll|}
\hline No. & Pop. & Serial No. & longitude /N & Latitude & samples size \\
& & & & /E & \\
\hline 1 & ZhongjiaoDong & ZJD & $112^{\circ} 04^{\prime} 01^{\prime \prime}$ & $22^{\circ} 24^{\prime} 16^{\prime \prime}$ & 33 \\
\hline 2 & Tankui Village & TK & $112^{\circ} 04^{\prime} 30^{\prime \prime}$ & $22^{\circ} 24^{\prime} 22^{\prime \prime}$ & 16 \\
\hline 3 & G325 National Roadside, & ZY & $112^{\circ} 03^{\prime} 59^{\prime \prime}$ & $22^{\circ} 24^{\prime} 26^{\prime \prime}$ & 25 \\
\hline 4 & XingfuVillage, & $\mathrm{XFC}$ & $112^{\circ} 00^{\prime} 41^{\prime \prime}$ & $22^{\circ} 21^{\prime} 54^{\prime \prime}$ & 18 \\
\hline 5 & National Geopark, & $\mathrm{GY}$ & $111^{\circ} 49^{\prime} 51^{\prime \prime}$ & $22^{\circ} 35^{\prime} 19^{\prime \prime}$ & 19 \\
\hline 6 & Dianbai District, Maoming & $\mathrm{MM}$ & $111^{\circ} 12^{\prime} 21^{\prime \prime}$ & $21^{\circ} 45^{\prime} 52^{\prime \prime}$ & 10 \\
\hline 7 & Datong Village & $\mathrm{YC}$ & $111^{\circ} 58^{\prime} 48^{\prime \prime}$ & $22^{\circ} 23^{\prime} 25^{\prime \prime}$ & 20 \\
\hline
\end{tabular}

Table 2 Efficiency of PCR and sequence characterization of DNA barcodes

\begin{tabular}{|lllllll|}
\hline & $\begin{array}{l}\text { numbers } \\
\text { of } \\
\text { sequences }\end{array}$ & $\begin{array}{l}\text { PCR } \\
\text { amplification } \\
\text { success rate }(\%)\end{array}$ & $\begin{array}{l}\text { sequencing } \\
\text { success rate } \\
(\%)\end{array}$ & $\begin{array}{l}\text { average } \\
\text { sequence } \\
\text { length /bp }\end{array}$ & $\begin{array}{l}\text { GC } \\
\text { content } \\
\text { /\% }\end{array}$ & $\begin{array}{l}\text { conservative } \\
\text { sites }\end{array}$ \\
\hline ITS2 & 134 & 95.74 & 95.04 & 229 & 59.83 & 229 \\
\hline $\begin{array}{l}\text { psbA- } \\
\text { trnH }\end{array}$ & 76 & 57.45 & 53.90 & 667 & 28.49 & 667 \\
\hline ITS & 139 & 99.29 & 98.58 & 653 & 56.20 & 653 \\
\hline matK & 41 & 29.08 & 29.08 & 787 & 29.22 & 787 \\
\hline rbcL & 141 & 100.00 & 100.00 & 729 & 41.84 & 729 \\
\hline
\end{tabular}

Table 3 ISSR banding patterns of seven $A$. villosum populations. 


\begin{tabular}{|c|c|c|c|c|c|}
\hline primers & sequences & $\operatorname{Tm}\left({ }^{\circ} \mathrm{C}\right)$ & amplification bands & polymorphic bands & PPB(\%) \\
\hline UBC808 & $(\mathrm{AG})_{8} \mathrm{C}$ & 52.00 & 11 & 11 & 100.00 \\
\hline UBC817 & $(\mathrm{CA})_{8} \mathrm{~A}$ & 49.24 & 11 & 10 & 90.91 \\
\hline UBC825 & $(\mathrm{AC})_{8} \mathrm{~T}$ & 52.00 & 12 & 12 & 100.00 \\
\hline UBC840 & $(\mathrm{GA})_{8} \mathrm{YT}$ & 52.74 & 12 & 10 & 83.33 \\
\hline UBC866 & $(\mathrm{CTC})_{6}$ & 56.60 & 6 & 4 & 66.67 \\
\hline UBC889 & $\mathrm{DBD}-(\mathrm{AC})_{7}$ & 46.83 & 14 & 9 & 64.29 \\
\hline sum & - & - & 66 & 56 & 84.85 \\
\hline mean & - & - & 11 & 9.33 & 84.82 \\
\hline
\end{tabular}

Table 4 Genetic diversity of $A$. villosum populations based on ISSR.

\begin{tabular}{|lllllll|}
\hline & NO. & $\mathrm{Na}$ & $\mathrm{Ne}$ & $\mathrm{H}$ & $\mathrm{I}$ & $\mathrm{PPB}(\%)$ \\
\hline ZJD & 9 & 1.5303 & 1.3492 & 0.1998 & 0.2954 & 53.03 \\
\hline TK & 4 & 1.2879 & 1.1848 & 0.1117 & 0.1658 & 28.79 \\
\hline ZY & 7 & 1.7121 & 1.4240 & 0.2536 & 0.3816 & 71.21 \\
\hline XFC & 5 & 1.4394 & 1.2685 & 0.1624 & 0.2434 & 43.94 \\
\hline GY & 5 & 1.4848 & 1.3516 & 0.1998 & 0.2897 & 48.48 \\
\hline MM & 3 & 1.4901 & 1.3273 & 0.1818 & 0.2604 & 40.91 \\
\hline YC & 5 & 1.4394 & 1.2753 & 0.1648 & 0.2460 & 43.94 \\
\hline mean & 7 & 1.4834 & 1.3115 & 0.1820 & 0.2689 & 47.19 \\
\hline At species level & 38 & 1.9394 & 1.5662 & 0.3281 & 0.4895 & \\
\hline
\end{tabular}

Table 5 Genetic structure of $A$. villosum populations based on ISSR 


\begin{tabular}{|lllll|}
\hline $\begin{array}{l}\text { samples } \\
\text { size }\end{array}$ & $\begin{array}{l}\text { genetic diversity of the } \\
\text { total populations }(\mathrm{Ht})\end{array}$ & $\begin{array}{l}\text { genetic diversity within } \\
\text { populations }(\mathrm{Hs})\end{array}$ & $\begin{array}{l}\text { gene } \\
\text { differentiation } \\
\text { coefficient } \\
(\mathrm{Gst})\end{array}$ & $\begin{array}{c}\text { gene } \\
\text { flow } \\
(\mathrm{Nm})\end{array}$ \\
38 & 0.3299 & 0.1819 & 0.4487 & 0.6143 \\
$\begin{array}{l}\text { standard } \\
\text { deviation }\end{array}$ & \pm 0.0272 & \pm 0.0102 & - & - \\
\hline
\end{tabular}

Table 6 AMOVA analysis of $\boldsymbol{A}$. villosum populations based on ISSR

\begin{tabular}{|lllllll|}
\hline $\begin{array}{l}\text { source of } \\
\text { variation }\end{array}$ & $\begin{array}{l}\text { degree of } \\
\text { freedom } \\
\text { /df }\end{array}$ & $\begin{array}{l}\text { mean } \\
\text { square } \\
\text { deviation } \\
\text { /SS }\end{array}$ & $\begin{array}{l}\text { mean } \\
\text { square } \\
\text { value } \\
\text { /MS }\end{array}$ & $\begin{array}{l}\text { variance } \\
\text { component }\end{array}$ & $\begin{array}{l}\text { variance } \\
\text { component } \\
\text { percentage }(\%)\end{array}$ & $P$ \\
\hline $\begin{array}{l}\text { among } \\
\text { populations }\end{array}$ & 6 & 167.835 & 27.972 & 3.718 & 31.26 & 0.001 \\
\hline $\begin{array}{l}\text { within } \\
\text { populations }\end{array}$ & 37 & 253.455 & 8.176 & 8.176 & 68.74 & 0.001 \\
\hline sum & 43 & 421.289 & - & 11.894 & 100 & - \\
\hline
\end{tabular}

Table 7 Nei's genetic distance of $A$. villosum populations

\begin{tabular}{|llllllll|}
\hline & ZJD & TK & ZY & XFC & GY & MM & YC \\
ZJD & 0.0000 & & & & & & \\
\hline TK & 0.0844 & 0.0000 & & & & & \\
\hline ZY & 0.0973 & 0.1247 & 0.0000 & & & & \\
\hline XFC & 0.2347 & 0.3317 & 0.1957 & 0.0000 & & & \\
GY & 0.2260 & 0.2697 & 0.1946 & 0.1463 & 0.0000 & & \\
MM & 0.2785 & 0.2827 & 0.2218 & 0.2342 & 0.1132 & 0.0000 & \\
\hline YC & 0.2697 & 0.2719 & 0.2176 & 0.3347 & 0.2003 & 0.1382 & 0.0000 \\
\hline
\end{tabular}


Figures

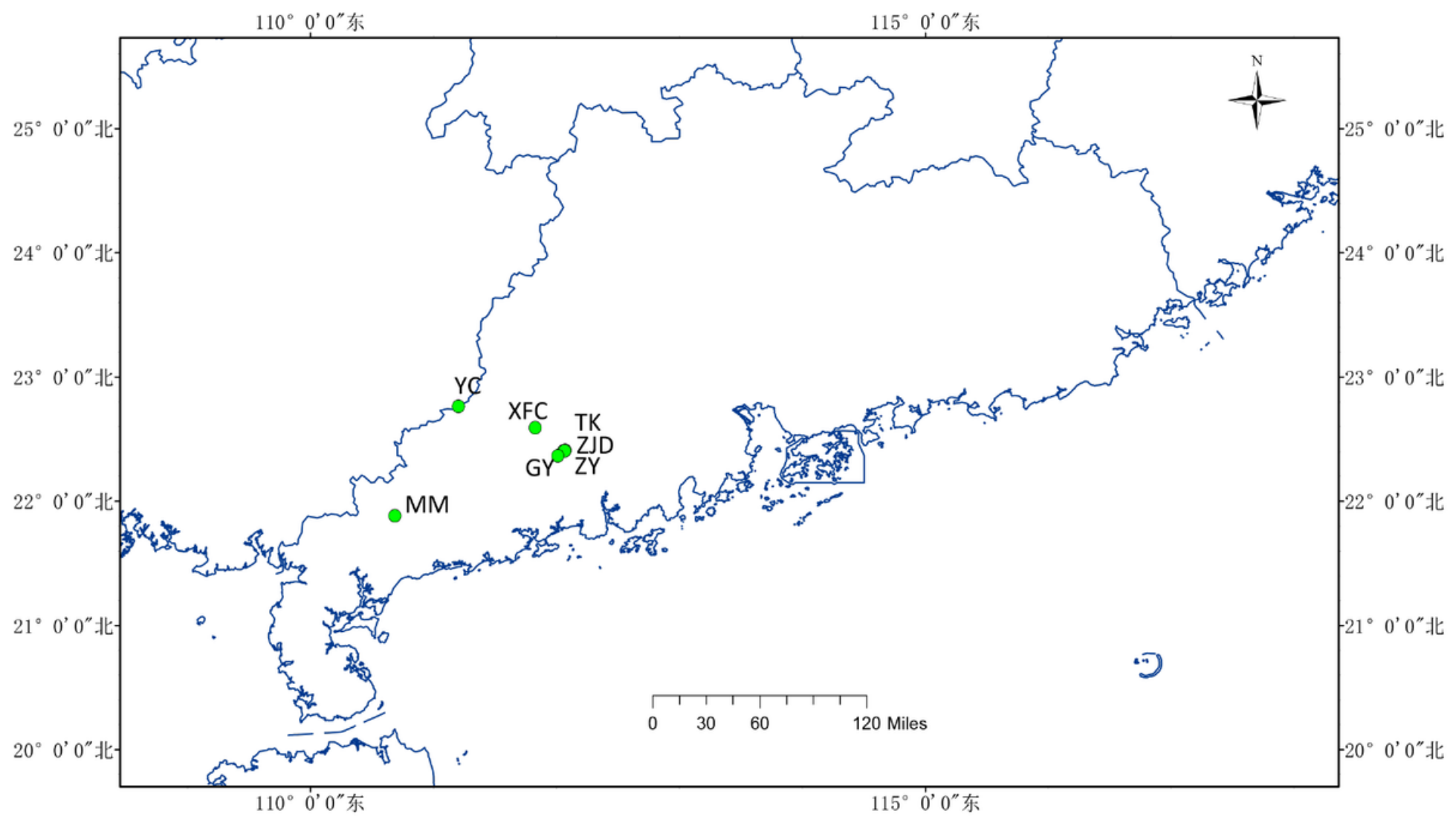

\section{Figure 1}

Geographical distribution of collected A. villosum populations Note: The designations employed and the presentation of the material on this map do not imply the expression of any opinion whatsoever on the part of Research Square concerning the legal status of any country, territory, city or area or of its authorities, or concerning the delimitation of its frontiers or boundaries. This map has been provided by the authors. 
(a)

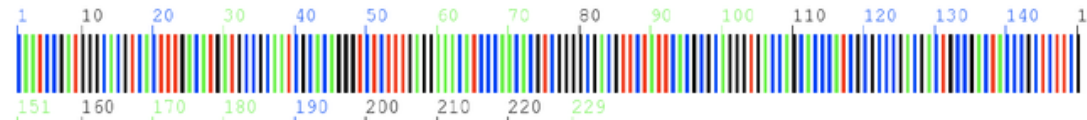

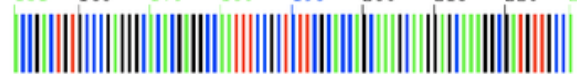
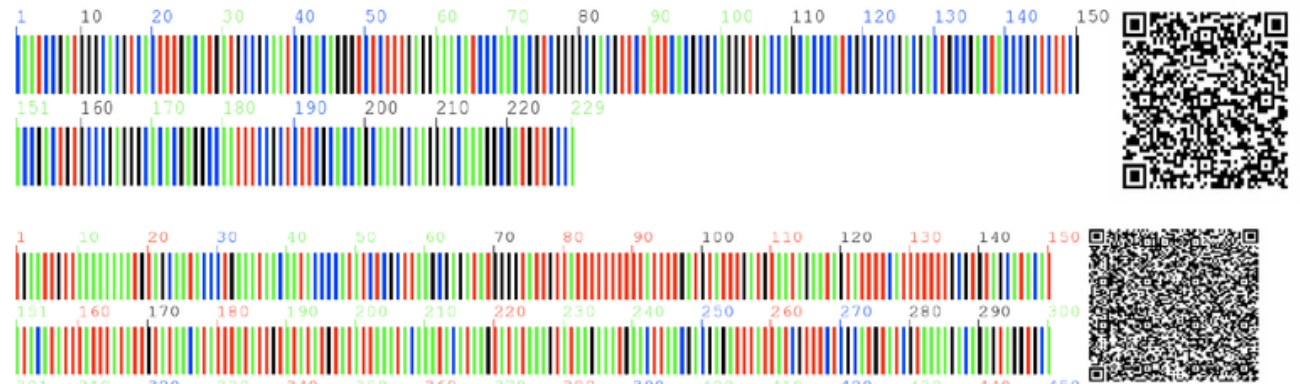

(b)
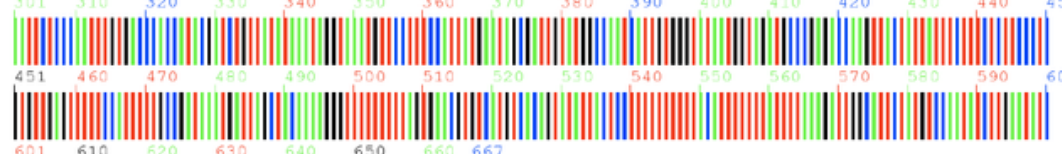
||||||||||||||||||||||||||||||||||||||||||||||||||||||

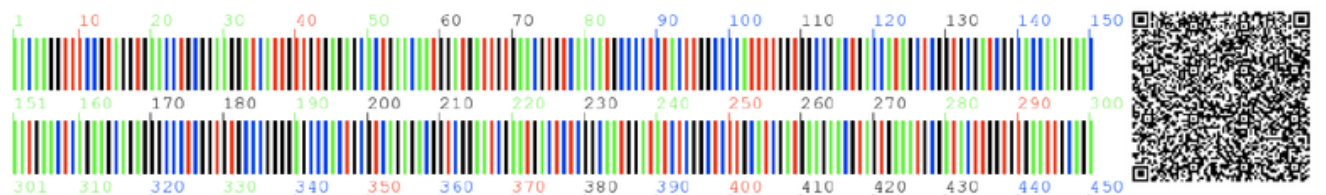

(c)
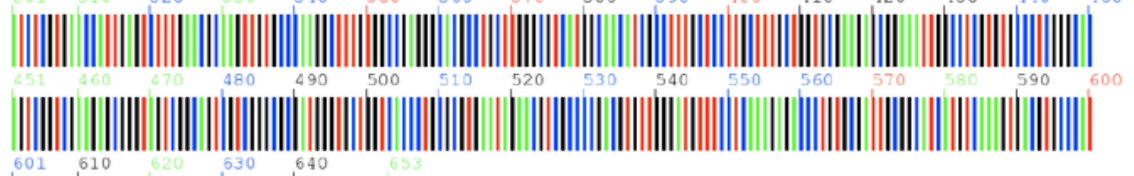

$601 \underbrace{}_{610}$

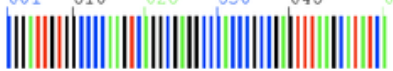

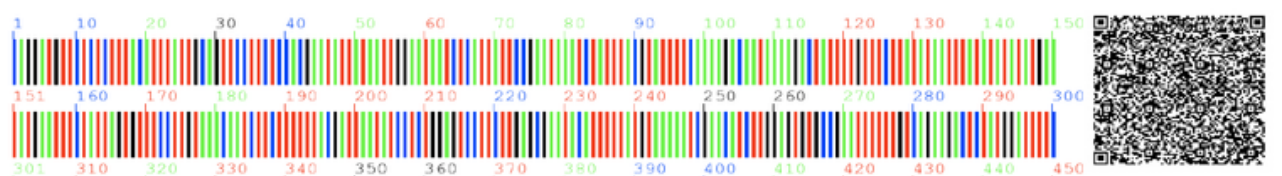

(d)
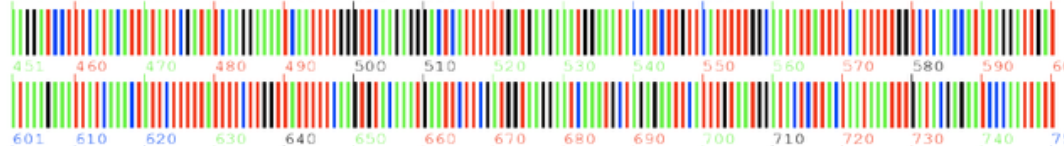

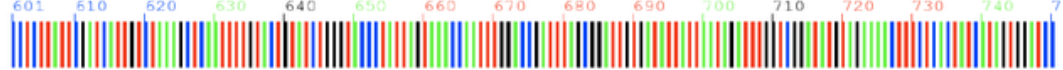

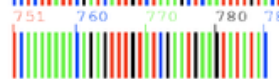

(e)

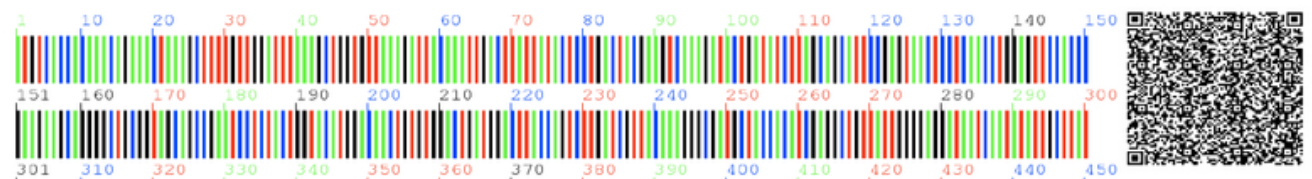

\section{Figure 2}

DNA barcode sequences of $A$. villosum. 


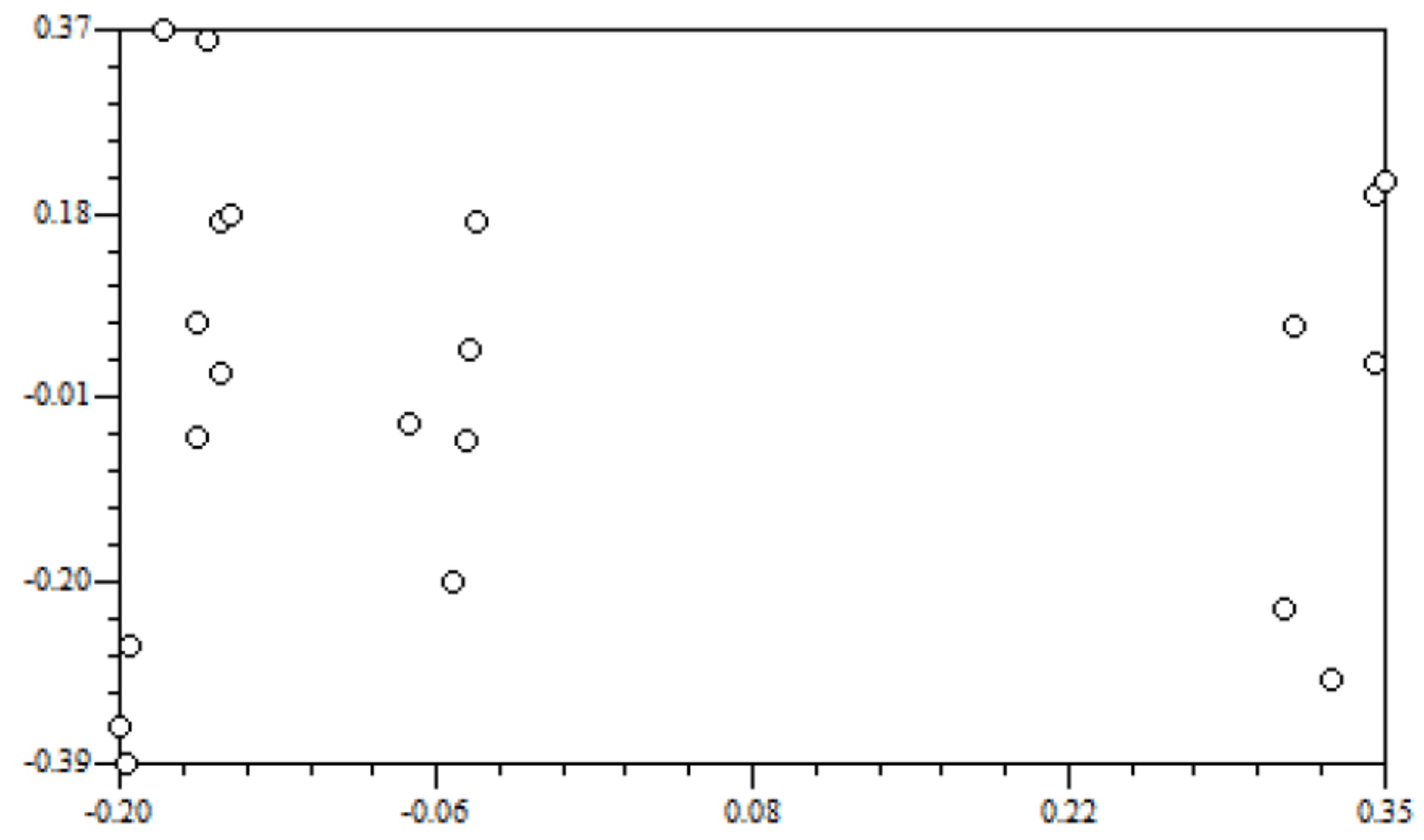

Figure 3

Correlation of geographic distance and genetic distance 


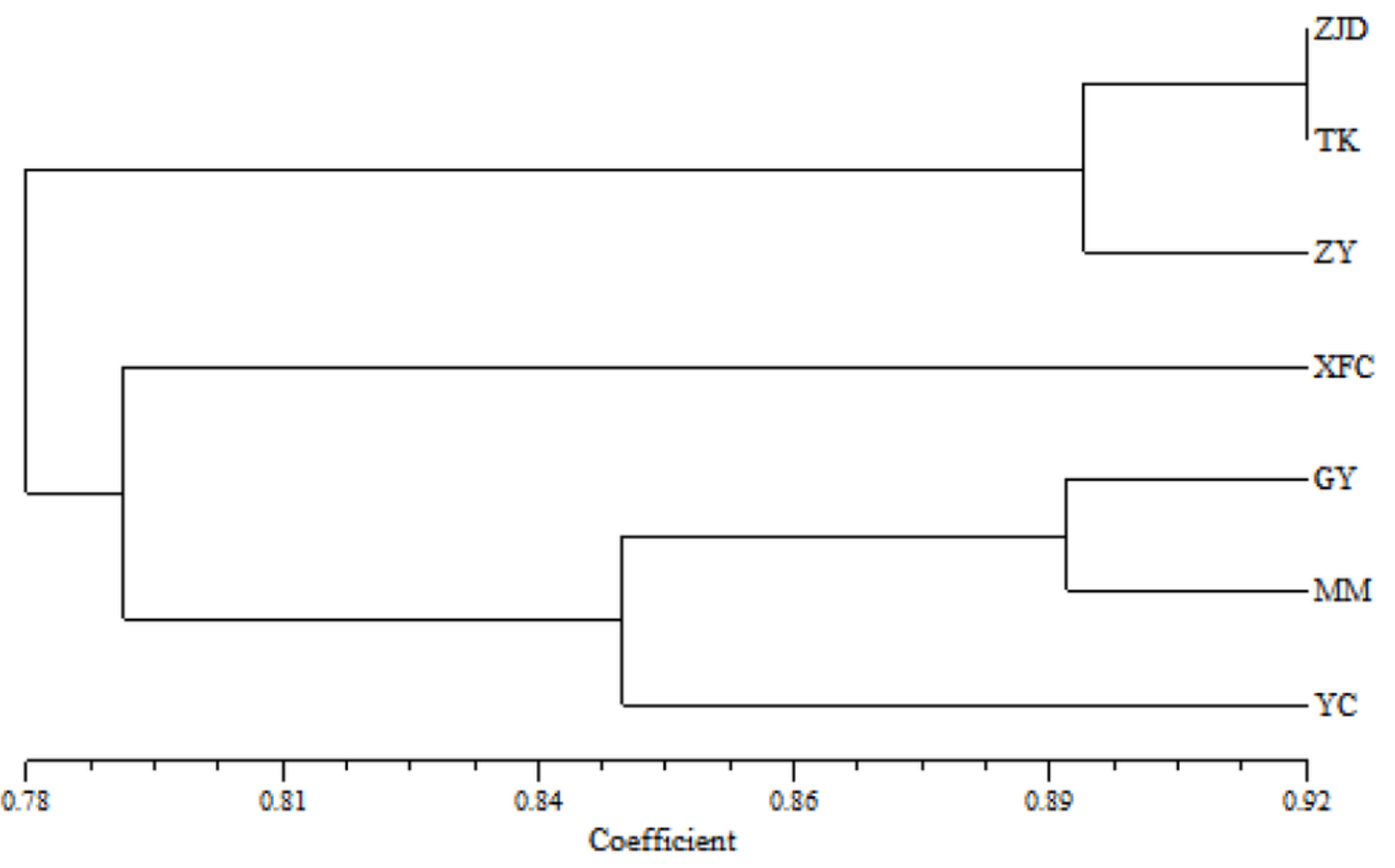

Figure 4

UPGMA clustering map of A. villosum populaitons

Principal Coordinates (PCoA)

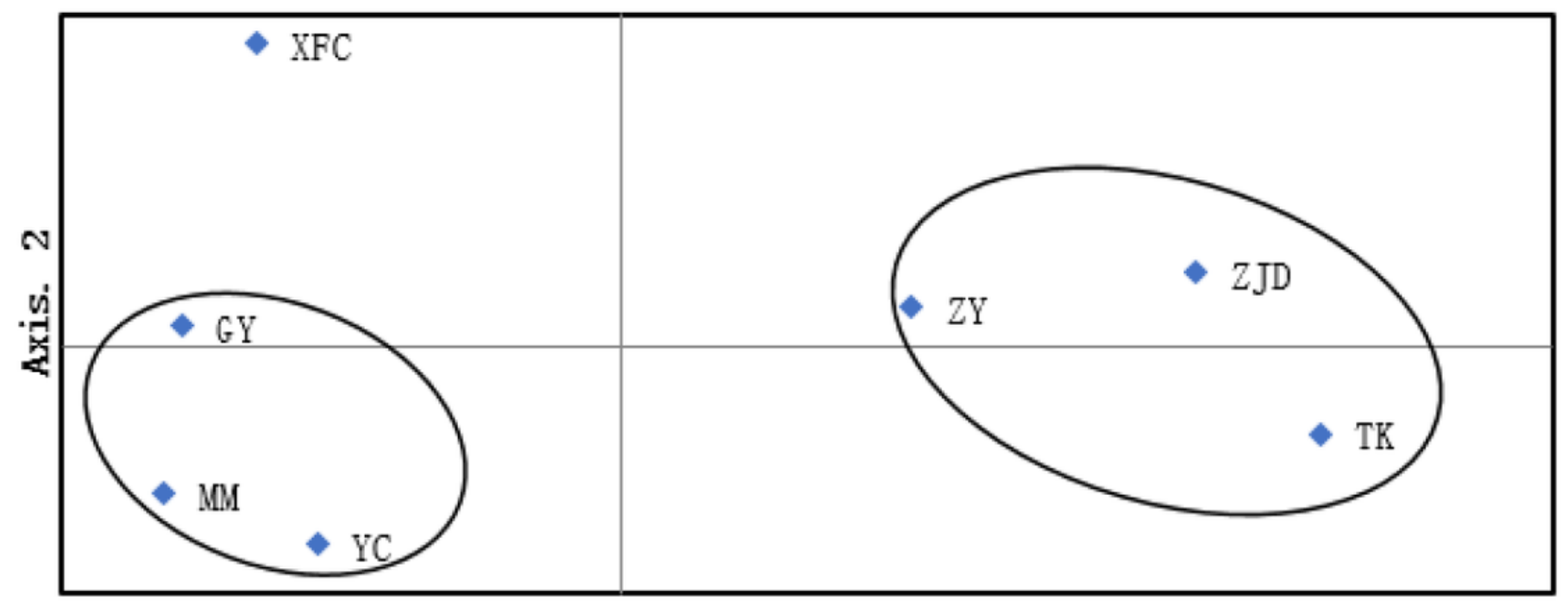

Axis. 1

Figure 5 
PCoA map of A. villosum populations (coord. $1=48.04 \%$ and coord. $2=26.74 \%$ )

\section{Supplementary Files}

This is a list of supplementary files associated with this preprint. Click to download.

- supplementarymaterials.docx 